Relations industrielles

Industrial Relations

\title{
Zippay, Allison, From Middle Income to Poor : Downward Mobility Among Displaced Steelworkers
}

\section{Charles J. McCollester}

Volume 48, numéro 1, 1993

URI : https://id.erudit.org/iderudit/050847ar

DOI : https://doi.org/10.7202/050847ar

Aller au sommaire du numéro

Éditeur(s)

Département des relations industrielles de l'Université Laval

ISSN

0034-379X (imprimé)

1703-8138 (numérique)

Découvrir la revue

Citer ce compte rendu

McCollester, C. J. (1993). Compte rendu de [Zippay, Allison, From Middle Income to Poor : Downward Mobility Among Displaced Steelworkers]. Relations industrielles / Industrial Relations, 48(1), 207-209.

https://doi.org/10.7202/050847ar

Tous droits réservés @ C Département des relations industrielles de l'Université Laval, 1993
Ce document est protégé par la loi sur le droit d'auteur. L’utilisation des services d'Érudit (y compris la reproduction) est assujettie à sa politique d'utilisation que vous pouvez consulter en ligne.

https://apropos.erudit.org/fr/usagers/politique-dutilisation/ 
most readers of this point. Higher wage workers are more likely to be covered by employer plans and workers who become unemployed or change jobs frequently build up few entitlements in defined-benefit plans. As a result, the distribution of retirement income is much more skewed than the distribution of income from employment.

In Canada, the Canada Pension Plan is intended to provide a floor of income support for retired workers. Other means-tested programs provide a supplement. Private pension plans and Registered Retirement Savings Plans round out this system. In general terms, this is similar to the U.S. system. The problems of the U.S system with regard to coverage, adequacy and the other problem areas identified by Ghilarducci are largely shared by the Canadian system.

Ghilarducci's proposed reforms for this system are radical. She would replace all private pensions with a "democratized" universal public system. The generally interventionist flavour of most of this book is shown by her proposal to use the funds accumulated in such a system as "a means to finance a national industrial policy" (p. 175). The problems with the existing pension system are well-documented in this book but this is less true for the solutions.

Douglas A. SMITH

Carleton University

From Middle Income to Poor: Downward Mobility among Displaced Steelworkers, by Allison ZrPPaY, New York, Praeger Book News, 1991, 144 p., ISBN 0-275-93791-7

Allison Zippay has written an insightful and useful sociological study about the officially unmourned victims of the precipitous industrial decline of the U.S. "Unmourned" because in the 1980 's, the nation's leadership and media generally portrayed the industrial collapse of what had been the world's leading producing nation as an insignificant subplot to the surface glitter and self-preoccupation of the Reagan years. While the President (amplified by a chorus of national and local "opinion makers") proclaimed that the transition to a postindustrial, service economy was a great economic advance, the media, by and large, unable to decide whether the demise of the mills was to be mourned or celebrated, proclaimed events inevitable and passed guickly on with barely a sideways glance at the tragic consequences of a nation's failed labor and industrial policy.

The "tragic consequences" are the subject of Zippay's book, which studies a slice of one hundred workers at two plants in the Shenango Valley on Pennsylvania's Western border with Ohio. The largest town in the area is Sharon, $\mathrm{Pa}$. not far from Youngstown, Ohio, where some of the most vocal and organized local resistance to Washington's laissez-faire economic policies of the 1980's was mounted. The book does not present a journalistic reconstruction of events, nor an economic analysis of their causes, but rather takes a cross-sectional survey of a group of dislocated industrial workers in a "run of the mill", "rust-belt" town, describes their plight and makes a pointed but limited attempt to explain the significance of their fate. 
Using interviews with dislocated workers and 22 directors of social service agencies, the author effectively expresses the sense of isolation felt by an abandonned industrial workforce. In their tight-knit, ethnic towns and neighborhoods, with their strong communitarian and collective values, these industrial toilers truly lived in "another country". Performing a physically demanding, dirty and dangerous occupation, hidden from public view by dilapidated walls of rusting sheet metal, these workers occupy less of an identifiable niche in the nation's psyche than do unemployed ghetto youth or even the rural poor of Appalachia. Unlike the years of the Great Depression when the uprising of the industrial workforce articulated the aspirations of an entire nation in crisis, the pain-filled outcry of the milltowns failed to resonate in Reagan's America anesthetized by a debt-concocted prosperity.

Ironically, Zippay points out that Rand McNally in its 1985 nationwide "quality of life" survey ranked Sharon the "least cultured" town in the United States. This recalled to mind the rage expressed by my country cousins when their rural, far northern New York county was proclaimed "culturally deprived" by Albany bureaucrats. They felt that raising cows, working the land and supporting their children's educational endeavors constituted a rich culture. With their class-based blinders, the definers of national culture understand very little about a work-based culture centered on family, ethnic church and union hall, whose main recreational activity is hunting and fishing in woods and waters far from their dark, satanic mills. Even in their spare time, these workers spent most of their time making and repairing things, remodeling houses and fixing cars.

The milltown's isolation from mainstream national concerns was starkly exposed by the uncoordinated and inadequate governmental response to the crisis. Existing social services established to deal with relatively marginal unemployment, were totally unprepared to respond to the devastation caused by multiple plant closings. While social services struggled to cope with geometrically expanding demand, both state and national governments were in the hands of conservative, right wing politicians dedicated to the proposition that "less government is better." As traditional working class resistance to accepting public assistance was worn down by dire necessity, the displaced worker encountered an overwhelmed bureaucracy itself facing budget cuts.

The book documents the growth of informal networks that grew up to provide survival services like food banks, but also notes the lack of organized collective protest or resistance to the closings. No plan for the social and economic revitalization of the community was advanced by any level of government. When a small part of the area was struck by a tornado, disaster teams and counselors responded immediately, working closely with the victims, but when the whole region faced inexorable and enduring economic strangulation, those victims encountered silence.

Allison Zippay's book is a short, well constructed study of a phenomenon that deserves more attention from social scientists - the collapse of U.S. heavy industry. She succesfully and concisely describes the tragic downward mobility of America's blue collar working class. One weakness is that the extensive use of worker quotations that so enrich and humanize the dramatic data that she presents remain nameless and unidentified. Some identification at least of the speaker's age, occupation and seniority in the mill would have helped the reader visualize the faces behind the transcribed voices. 
Otherwise, she has succeeded in taking a rather limited cross-section of one small area of the rust belt and used it to raise broad questions about social solidarity and governmental responsibility that remain as yet unanswered.

Charles J. McCollester

Pennsylvania Center for the Study of Labor Relations, IUP

\section{A Portrait of Bureaucracy. The Bankruptcy of the Socialist System in Poland, by Adam Sarapata, Poznan, Delft, 1992, 227 p., ISBN 83-85308-07-5}

The disenchantment with the state socialist systems in eastern Europe had already been growing gradually much before the collapse of the Communist rule. The evidence of it in the Polish case is available much more than in other countries due to the developed sociological studies tolerated by the regime. Sarapata is a well known Polish sociologist in the field of work and management, and this book is a summary of his empirical studies done in the 1970s and the 1980s. According to J. Szczepanski in his introduction, (one of the most prominent contemporary Polish sociologists), this book "...explains, indirectly and directly, the perseverance of the stereotype of the relation between state and society as two opposing social entities, and also explains the perseverance of inclinations towards antagonistic actions ... The data contained in the book present the state of social consciousness and the strength of pressure exerted upon the decisions made by the authorities by the politically active masses." (p. 13).

It is worth adding that this high level of dissatisfaction has also continued under the postcommunist rule and from that perspective data collected by Sarapata illuminate the deep sources of socio-economic imbalance in Poland. The author demonstrates that undesirable attitudes towards work and the workplace are deeply rooted in poor working conditions, inadequate management, low level of democratization, and the more or less justified lack of confidence of subordinates in the professional and administrative competence of their supervisors. "The poor condition of Polish society and the dramatic situation of the country are closely linked to the faulty functioning of public administration, and the defects of the latter are bad omens for the future of both individuals and the country."' (p. 20)

Unfortunately, the depoliticization of the Polish economy (over $90 \%$ of bosses used to be either members of the Communist party or members of political bodies fully subordinated to the former), as well as progressing marketization and privatization, have so far not eliminated the roots of disenchantment, evidenced in the lack of genuine entrepreneurship, low administrative and managerial skills of the people in power at the local, regional or central levels, very low real incomes, and lack of a clear and convincing relationship between work and remuneration. While Sarapata relates these phenomena to the model of state socialism, there is also a continuation of old shortcomings under the new socio-economic order. In addition, the unemployment rate (13\% and growing) is a painful experience, especially for the young people who enter the labour market.

The first Chapter deals with aspirations, apprehensions and hopes of the Poles. According to 1984 data, Poles, especially unskilled workers, were much less happy than 